UNDERGRADUATE RESEARCH IN NATURAL AND CLINICAL SCIENCE AND TECHNOLOGY (URNCST) JOURNAL Read more URNCST Journal articles and submit your own today at: https://www.urncst.com

\title{
The Effect of Exercise on Leptin and Adiposity: A Systematic Review
}

Reem H. Tehfe, BHSc Student [1]*, Zaynab A. Elkhansa, BHSc Student [2], Sarah Fu, BHSc, MD [3], Hadi Tehfe, BHSc, MD [3]

[1] Department of Health Sciences, University of McMaster, Hamilton, ON, Canada L8S 4L8

[2] Department of Health Sciences, University of Ottawa, Ottawa, ON, Canada K1N 6N5

[3] Department of Undergraduate Medicine, University of Ottawa, Ottawa, ON,

Canada K1N 6N5

URNCST Journal

"Research in Earnest"

*Corresponding Author: tehfer@mcmaster.ca

\begin{abstract}
Introduction: Leptin has been characterized as an important regulator of metabolic homeostasis, functioning in the inhibition of food intake and promotion of energy expenditure. Leptin resistance has been implicated in the development of cardiovascular diseases and obesity, and as exercise programs are used as a therapeutic measure for these disorders, it is hypothesized that exercise will decrease concentrations of leptin in the blood.

Methods: A comprehensive literature search of MedLine was conducted from inception to September 2020. Relevant search terms include: Leptin, Obesity, Exercise, Physical activity, BMI, and Adiposity. Eligible randomized control trials (RCTs) include RCTs reporting on the effects of low, moderate or high intensive exercise on leptin concentration. We followed the search strategy based on PRISMA to report our systematic review, and assessed the studies independently and in duplicate for their risk of bias (ROB) using the Cochrane ROB2 tool. Statistical analysis was performed to compare ROB (categorized as "high" or "low/some") in relation to impact factor, number of citations, and number of authors.

Results: Forty-eight studies involving the relationship between physical exercise and leptin met the inclusion criteria. After completing the ROB, the relationships between ROB and impact factor $(0.2775, \mathrm{p}>0.6405)$, citation number $(2.059$, $\mathrm{p}>0.0962)$, and the number of authors $(-5.235, \mathrm{p}>0.5551)$ were determined.

Discussion: The leptin pathway involves an overactivation of mTOR contributing to the development of obesity, with this pathway being inhibited by physical activity. This corresponds to the findings that thirty-nine studies reported that physical exercise resulted in a statistically significant decrease in leptin levels as compared to the control group. However, the overall evidence was insufficient to suggest a statistically significant relationship between ROB and impact factor, citation number, and the number of authors.

Conclusion: This systematic review indicated an inverse relationship between physical exercise and leptin However, further research is needed to address the varying effects of physical activity on leptin and to define a more concrete relationship between risk of bias and the characteristics of studies in this field.
\end{abstract}

Keywords: leptin; physical exercise; obesity

\section{Introduction}

There is increasing evidence that leptin plays a vital role in the modulation of physiological processes related to individuals struggling with obesity and body weight. As a chemical messenger, leptin is released by adipocytes, and is stored proportionally to the individual's fat levels [1]. Leptin hormones signal the hypothalamus, which is involved in energy maintenance and other metabolic activities in order to facilitate the long-term regulation of food intake, energy, and overall body weight [2]. Leptin inhibits feelings of hunger, therefore earning the title of the "satiety hormone", and ultimately helping to maintain metabolic homeostasis [1].
The relationship between leptin and weight has been readily documented in literature. First, It has been hypothesized that individuals with obesity have excess levels of leptin within their bloodstream, and in turn, become desensitized to leptin, thus developing leptin resistance [3]. This resistance causes an insatiable hunger drive, prompting excess eating, thus increasing weight and leptin levels. On the other hand, dieting assists individuals with weight loss, therefore resulting in a reduction in fat tissue and leptin levels [4,5]. This, however, leads to increased appetite as a result, creating barriers to further dieting and weight loss. Occasionally, some individuals may have congenital leptin deficiency, which consequently leads to severe hunger [6]. 
UNDERGRADUATE RESEARCH IN NATURAL AND CLINICAL SCIENCE AND TECHNOLOGY (URNCST) JOURNAL Read more URNCST Journal articles and submit your own today at: https://www.urncst.com

This would encourage leptin-deficient individuals to incessantly ingest food, serving as a catalyst to obesity.

The effect of physical activity on leptin levels is controversial. Previous research has reported that exercise may reduce leptin levels, or it may have no effect at all [7-9]. As aforementioned, leptin levels and weight are positively correlated, therefore weight loss through exercise may consequently reduce leptin levels. However, there is opposing research suggesting that other modulators of the leptin system, such as cortisol, upregulate leptin in response to stimulators such as exercise [10].

The objective of this study is to first conduct a narrative review to evaluate the effect of physical activity on leptin levels in randomized controlled trials, with change in leptin levels as the primary outcome. Leptin is an important factor in understanding the variability of physical activity interventions. Uncovering the impact of exercise on the leptin system will help inform future clinical decisionmaking and allow us to better advise individuals struggling with weight loss. This study has additionally completed a systematic review of the quality of studies evaluating the effects of physical activity on leptin. By determining which factors increase bias in randomized control trials of physical activity and leptin, these findings can be used by policy makers and clinicians when deciding which study findings should be implemented into clinical practice.

\section{Methods}

Search Strategy

A comprehensive literature search was conducted in the Medline database from inception to September 2020. The search was restricted to the English language. According to the specific syntax of the Medline database, the following search terms were applied: leptin AND obesity AND (exercise OR physical activity), as well as BMI and adiposity. Studies that were not randomized control trials (observational studies, narrative studies, systematic reviews, cohort studies, case reports etc.) were excluded. Further, the references of relevant articles identified by the search were scanned to reveal any other relevant studies. The COVIDENCE tool was then used to compile the studies obtained from the manual search and database, manually removing duplicates in the process. Independently and in duplicate, two authors (R. T. and Z. E.) reviewed all abstracts and titles for inclusion or exclusion. Conflicts were resolved with the help of two third parties (S. F. and H. T.).

\section{$\underline{\text { Selection Criteria }}$}

The following inclusion criteria was used in the article selection process: (1) participants in the intervention and control groups must have their leptin measures recorded at baseline and post-intervention; (2) must include a physical activity intervention (any physical activity intervention which exceeded levels of a sedentary control, ranging from light to vigorous physical activity); (3) must be a randomized control trial. Studies were similarly excluded if they were: (1) non-human studies (cadaver or animal); (2) non-English studies.

\section{Data Extraction}

After completing the full-text review, the two authors (R. T. and Z. E.) independently and in duplicate extracted the following data from the studies: general study characteristics (year of publication, first author name, and journal name), most recent available journal impact factor, number of citations as indicated by Google Scholar, number of authors, dichotomous conflict of interest statement $(\mathrm{Y} / \mathrm{N})$, and changes in leptin level (statistically significant decrease/no change/increase). After completion of the extracted forms, a third party (S. F. and H. T.) was once again recruited to resolve any conflicts. All data was extracted using Microsoft Excel.

\section{Risk of Bias}

Following data extraction, studies were further assessed by two authors (R. T. and Z. E.) independently and in duplicate for their risk of bias, using the Cochrane ROB2 tool. The following bias domains were examined: (1) bias arising from the randomization process, (2) bias due to deviations from the intended intervention, (3) bias due to missing outcome data, (4) bias in measurement of the outcome, and (5) bias in selection of the reported result. Each bias domain received a score of low risk of bias, some concerns or high risk of bias. Each study was then further given an overall risk of bias score using this same scale. Two third parties (S. F. and H. T.) were consulted when conflicts arose between the two authors. The ROBVIS software was used to visualize these scores.

\section{Statistical Analysis}

Statistical analysis regarding the quality of the studies were conducted by comparing overall risk of bias scores in relation to impact factor, number of citations, and number of authors. In order to obtain an adequate sample size for each of the groups, the 48 included studies were divided into two groups, high risk of bias and low/some risk of bias. Comparisons were conducted using two-tailed paired t-tests with a 95\% confidence interval via GraphPad PRISM.

\section{Results}

Study Selection and Characteristics

Results of the search strategy and selection were summarized in the following PRISMA flow chart seen in figure 1. After duplicates were identified, the search strategy presented 997 articles which contained this systematic review's keywords of interest (leptin, physical activity, obesity etc.) This was further narrowed to 116 articles for fulltext analysis, of which forty-eight were identified for extraction and risk of bias analysis. All forty-eight studies examined changes in leptin measures in response to some 
UNDERGRADUATE RESEARCH IN NATURAL AND CLINICAL SCIENCE AND TECHNOLOGY (URNCST) JOURNAL Read more URNCST Journal articles and submit your own today at: https://www.urncst.com

form of physical activity intervention, and thus all forty-eight studies were included in the analysis [11-58].

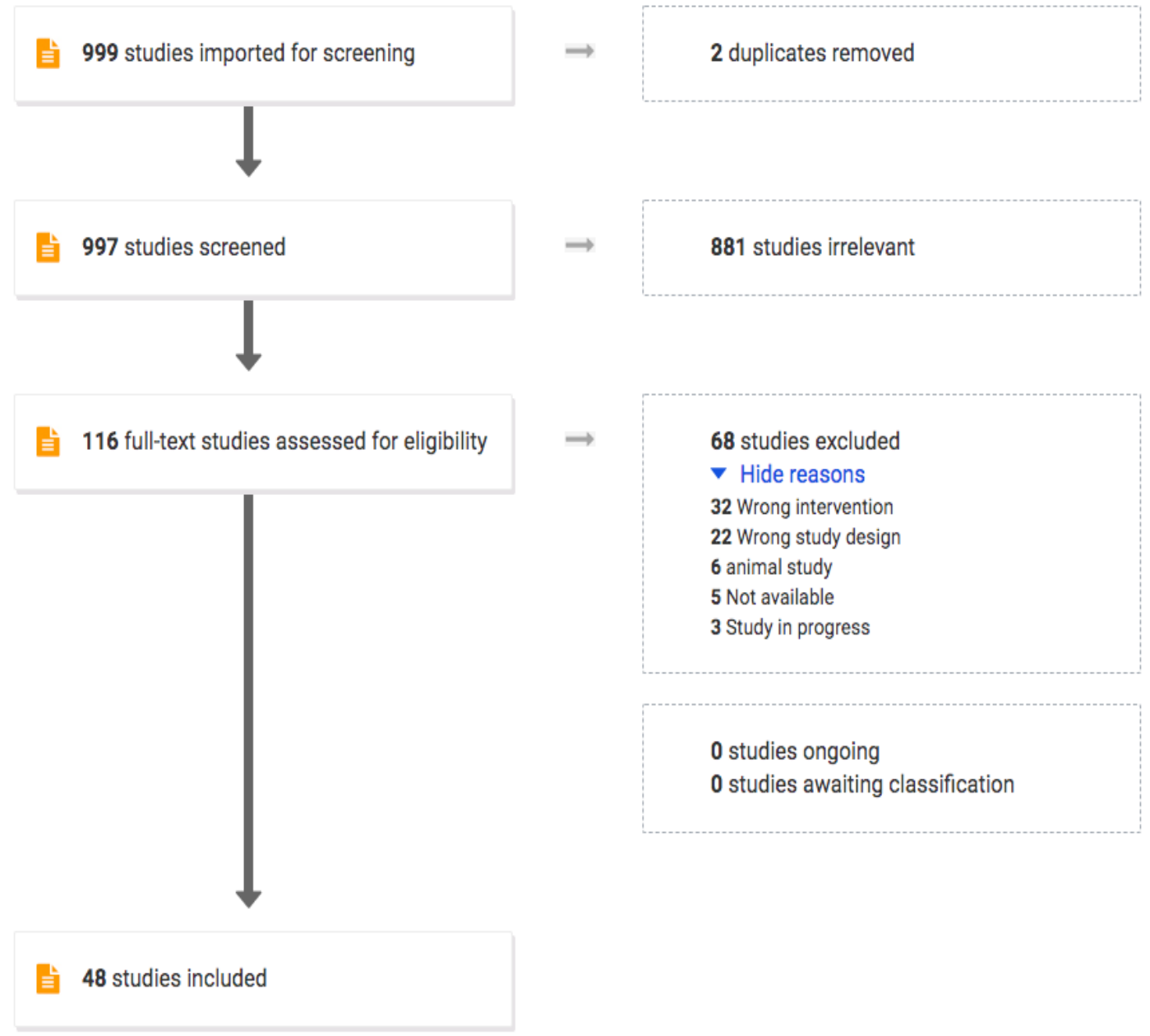

Figure 1. PRISMA flow diagram

Extracted information of the selected studies has been presented in Table 1. As none of the forty-eight studies identified any conflict of interests which may have otherwise interfered with the study quality, this dichotomous outcome was unimportant to the systematic review. Other characteristics, including impact factor, author number and citation number as identified by google scholar largely varied between the different studies and were thus a source of analysis. The primary outcome of changes in leptin levels was measured as a dichotomous variable, with "yes" representing a statistically decrease in leptin levels in the physical activity group as compared to the control, whereas a "no" represented either an increase or no change in leptin levels between groups. 
UNDERGRADUATE RESEARCH IN NATURAL AND CLINICAL SCIENCE AND TECHNOLOGY (URNCST) JOURNAL Read more URNCST Journal articles and submit your own today at: https://www.urncst.com

Table 1. Characteristics of the studies included in the systematic review

\begin{tabular}{|c|c|c|c|c|c|}
\hline Study & Impact Factor & Number of Authors & Citations on Google Scholar & Conflict of Interest $(\mathrm{Y} / \mathrm{N})$ & Was there a significant decrease in Leptin between the groups? \\
\hline \#912 - Balducci 2010 & 3.7 & 12 & 138 & $\mathrm{~N}$ & Yes \\
\hline \#143 - Sturgeon 2016 & 5.057 & 11 & 5 & $\mathrm{~N}$ & Yes \\
\hline \#921 - AsleMohammadiZadeh 2018 & 0.693 & 4 & 1 & $\mathrm{~N}$ & No \\
\hline \#833 - Cohen 2018 & 3.67 & 5 & 3 & $\mathrm{~N}$ & Yes \\
\hline \#835 - Clarson 2014 & 1.14 & 11 & 4 & $\mathrm{~N}$ & No \\
\hline \#773 - Dundar 2019 & 1.73 & 3 & 2 & $\mathrm{~N}$ & Yes \\
\hline \#803 - deOliveira 2010 & 2.45 & 3 & 0 & $\mathrm{~N}$ & Yes \\
\hline \#200 - SantaMina 2013 & 1.419 & 8 & 12 & $\mathrm{~N}$ & No \\
\hline \#828 - Cooper 2012 & 6.513 & 10 & 7 & $\mathrm{~N}$ & Yes \\
\hline$\# 678$ - McNeil 2015 & 6.31 & 6 & 6 & $\mathrm{~N}$ & Yes \\
\hline \#494 - Gonseth 2014 & 2.69 & 7 & 2 & $\mathrm{~N}$ & Yes \\
\hline \#645 - Morell-Azanza 2019 & 2.083 & 7 & 2 & $\mathrm{~N}$ & Yes \\
\hline \#167 - Sjögren 2012 & 3.004 & 10 & 5 & $\mathrm{~N}$ & Yes \\
\hline \#799 - DekkerNitert 2015 & 1.644 & 6 & 37 & $\mathrm{~N}$ & No \\
\hline \#859 - Brown 2018 & 3.671 & 11 & 8 & $\mathrm{~N}$ & Yes \\
\hline \#238 - Rogers 2013 & 2.657 & 10 & 96 & $\mathrm{~N}$ & Yes \\
\hline \#99 - Tremblay 2019 & 3.455 & 14 & 9 & $\mathrm{~N}$ & Yes \\
\hline \#700 - Markofski 2014 & 5.236 & 7 & 50 & $\mathrm{~N}$ & Yes \\
\hline \#226 - Rosety-Rodriguez 2013 & 0.566 & 8 & 21 & $\mathrm{~N}$ & Yes \\
\hline$\# 348$ - Kim 2019 & 2.849 & 4 & 5 & $\mathrm{~N}$ & Yes \\
\hline \#94 - Turner 2010 & 6.766 & 4 & 29 & $\mathrm{~N}$ & Yes \\
\hline \#353 - Khosravi 2018 & 1.326 & 7 & 0 & $\mathrm{~N}$ & Yes \\
\hline \#81 - vanPoppel 2019 & 7.518 & 25 & 8 & $\mathrm{~N}$ & Yes \\
\hline \#795 - Demark-Wahnefried 2017 & 5.791 & 12 & 6 & $\mathrm{~N}$ & Yes \\
\hline \#907 - Bartlett 2017 & 5.163 & 7 & 13 & $\mathrm{~N}$ & Yes \\
\hline \#257 - Loria-Kohen 2013 & 6.77 & 6 & 5 & $\mathrm{~N}$ & Yes \\
\hline \#995 - Ackel-D'Elia 2014 & 2.16 & 9 & 10 & $\mathrm{~N}$ & Yes \\
\hline \#908 - Barbeau 2003 & 2.95 & 8 & 7 & $\mathrm{~N}$ & No \\
\hline \#672 - Mendham 2014 & 3.02 & 4 & 6 & $\mathrm{~N}$ & Yes \\
\hline \#135 - Swisher 2015 & 2.86 & 8 & 30 & $\mathrm{~N}$ & Yes \\
\hline \#451 - Henning 2018 & 4.311 & 12 & 4 & $\mathrm{~N}$ & No \\
\hline \#914 - Balagopal 2010 & 3.742 & 7 & 14 & $\mathrm{~N}$ & Yes \\
\hline \#941 - Chen 2018 & 4.32 & 4 & 1 & $\mathrm{~N}$ & Yes \\
\hline \#927 - Arikawa 2018 & 1.76 & 4 & 3 & $\mathrm{~N}$ & Yes \\
\hline \#401 - Ihalainen 2018 & 3.255 & 8 & 5 & $\mathrm{~N}$ & Yes \\
\hline \#411 - Huang 2015 & 3.47 & 6 & 5 & $\mathrm{~N}$ & Yes \\
\hline$\# 664$ - Miller 2014 & 1.94 & 9 & 5 & $\mathrm{~N}$ & Yes \\
\hline \#406 - Hvid 2016 & 2.34 & 8 & 10 & $\mathrm{~N}$ & No \\
\hline \#393 - Janjgava 2014 & 1.826 & 5 & 7 & $\mathrm{~N}$ & No \\
\hline \#413 - Hossain 2018 & 1.734 & 6 & 2 & $\mathrm{~N}$ & Yes \\
\hline \#777 - Dorling 2019 & 4.21 & 8 & 0 & $\mathrm{~N}$ & Yes \\
\hline \#727 - Friedenreich 2011 & 4.8 & 15 & 33 & $\mathrm{~N}$ & Yes \\
\hline \#235 - Rokling-Andersen 2007 & 6.66 & 8 & 38 & $\mathrm{~N}$ & Yes \\
\hline$\# 901$ - Beavers 2013 & 4.19 & 4 & 26 & $\mathrm{~N}$ & Yes \\
\hline \#207 - Salas-Salvadó 2019 & 16.019 & 36 & 26 & $\mathrm{~N}$ & Yes \\
\hline \#794 - Demark-Wahnefried 2020 & 5.145 & 13 & 0 & $\mathrm{~N}$ & Yes \\
\hline \#776 - Douglas 2015 & 3.76 & 8 & 10 & $\mathrm{~N}$ & No \\
\hline \#537 - Reseland 2001 & 6.66 & 7 & 26 & $\mathrm{~N}$ & Yes \\
\hline
\end{tabular}


UNDERGRADUATE RESEARCH IN NATURAL AND CLINICAL SCIENCE AND TECHNOLOGY (URNCST) JOURNAL Read more URNCST Journal articles and submit your own today at: https://www.urncst.com

\begin{tabular}{|c|c|c|c|c|c|}
\hline Study & Impact Factor & Number of Authors & Citations on Google Scholar & Conflict of Interest $(\mathrm{Y} / \mathrm{N})$ & Was there a significant decrease in Leptin between the groups? \\
\hline \#912- Balducci 2010 & 3.70 & 12 & 138 & $\mathrm{~N}$ & Yes \\
\hline \#143 - Sturgeon 2016 & 5.06 & 11 & 5 & $\mathrm{~N}$ & Yes \\
\hline \#921 - AsleMohammadiZadeh 2018 & 0.69 & 4 & 1 & $\mathrm{~N}$ & No \\
\hline \#833 - Cohen 2018 & 3.67 & 5 & 3 & $\mathrm{~N}$ & Yes \\
\hline \#835 - Clarson 2014 & 1.14 & 11 & 4 & $\mathrm{~N}$ & No \\
\hline \#773 - Dundar 2019 & 1.73 & 3 & 2 & $\mathrm{~N}$ & Yes \\
\hline \#803- deOliveira 2010 & 2.45 & 3 & 0 & $\mathrm{~N}$ & Yes \\
\hline$\# 200$ - SantaMina 2013 & 1.42 & 8 & 12 & $\mathrm{~N}$ & No \\
\hline \#828 - Cooper 2012 & 6.51 & 10 & 7 & $\mathrm{~N}$ & Yes \\
\hline$\# 678$ - McNeil 2015 & 6.31 & 6 & 6 & $\mathrm{~N}$ & Yes \\
\hline \#494 - Gonseth 2014 & 2.69 & 7 & 2 & $\mathrm{~N}$ & Yes \\
\hline \#645-Morell-Azanza 2019 & 2.08 & 7 & 2 & $\mathrm{~N}$ & Yes \\
\hline \#167-Sjögren 2012 & 3.00 & 10 & 5 & $\mathrm{~N}$ & Yes \\
\hline \#799- DekkerNitert 2015 & 1.64 & 6 & 37 & $\mathrm{~N}$ & No \\
\hline \#859 - Brown 2018 & 3.67 & 11 & 8 & $\mathrm{~N}$ & Yes \\
\hline \#238 - Rogers 2013 & 2.66 & 10 & 96 & $\mathrm{~N}$ & Yes \\
\hline \#99 - Tremblay 2019 & 3.46 & 14 & 9 & $\mathrm{~N}$ & Yes \\
\hline$\# 700$ - Markofski 2014 & 5.24 & 7 & 50 & $\mathrm{~N}$ & Yes \\
\hline \#226-Rosety-Rodriguez 2013 & 0.57 & 8 & 21 & $\mathrm{~N}$ & Yes \\
\hline$\# 348$ - Kim 2019 & 2.84 & 4 & 5 & $\mathrm{~N}$ & Yes \\
\hline \#94 - Turner 2010 & 6.77 & 4 & 29 & $\mathrm{~N}$ & Yes \\
\hline \#353 - Khosravi 2018 & 1.33 & 7 & 0 & $\mathrm{~N}$ & Yes \\
\hline$\# 81$ - vanPoppel 2019 & 7.52 & 25 & 8 & $\mathrm{~N}$ & Yes \\
\hline \#795 - Demark-Wahnefried 2017 & 5.79 & 12 & 6 & $\mathrm{~N}$ & Yes \\
\hline \#907 - Bartlett 2017 & 5.16 & 7 & 13 & $\mathrm{~N}$ & Yes \\
\hline \#257 - Loria-Kohen 2013 & 6.77 & 6 & 5 & $\mathrm{~N}$ & Yes \\
\hline \#995 - Ackel-D'Elia 2014 & 2.16 & 9 & 10 & $\mathrm{~N}$ & Yes \\
\hline \#908 - Barbeau 2003 & 2.95 & 8 & 7 & $\mathrm{~N}$ & No \\
\hline \#672-Mendham 2014 & 3.02 & 4 & 6 & $\mathrm{~N}$ & Yes \\
\hline$\# 135$ - Swisher 2015 & 2.86 & 8 & 30 & $\mathrm{~N}$ & Yes \\
\hline \#451 - Henning 2018 & 4.31 & 12 & 4 & $\mathrm{~N}$ & No \\
\hline \#914 - Balagopal 2010 & 3.74 & 7 & 14 & $\mathrm{~N}$ & Yes \\
\hline \#941 - Chen 2018 & 4.32 & 4 & 1 & $\mathrm{~N}$ & Yes \\
\hline \#927 - Arikawa 2018 & 1.76 & 4 & 3 & $\mathrm{~N}$ & Yes \\
\hline \#401 - Ihalainen 2018 & 3.26 & 8 & 5 & $\mathrm{~N}$ & Yes \\
\hline \#411 - Huang 2015 & 3.47 & 6 & 5 & $\mathrm{~N}$ & Yes \\
\hline \#664 - Miller 2014 & 1.94 & 9 & 5 & $\mathrm{~N}$ & Yes \\
\hline \#406-Hvid 2016 & 2.34 & 8 & 10 & $\mathrm{~N}$ & No \\
\hline \#393 - Janjgava 2014 & 1.83 & 5 & 7 & $\mathrm{~N}$ & No \\
\hline \#413-Hossain 2018 & 1.73 & 6 & 2 & $\mathrm{~N}$ & Yes \\
\hline \#777 - Dorling 2019 & 4.21 & 8 & 0 & $\mathrm{~N}$ & Yes \\
\hline \#727 - Friedenreich 2011 & 4.80 & 15 & 33 & $\mathrm{~N}$ & Yes \\
\hline \#235- Rokling-Andersen 2007 & 6.66 & 8 & 38 & $\mathrm{~N}$ & Yes \\
\hline \#901 - Beavers 2013 & 4.19 & 4 & 26 & $\mathrm{~N}$ & Yes \\
\hline \#207 - Salas-Salvadó 2019 & 16.02 & 36 & 26 & $\mathrm{~N}$ & Yes \\
\hline \#794 - Demark-Wahnefried 2020 & 5.14 & 13 & 0 & $\mathrm{~N}$ & Yes \\
\hline \#776 - Douglas 2015 & 3.76 & 8 & 10 & $\mathrm{~N}$ & No \\
\hline \#537-Reseland 2001 & 6.66 & 7 & 26 & $\mathrm{~N}$ & Yes \\
\hline
\end{tabular}

\section{$\underline{\text { Risk of Bias }}$}

The following bias domains were examined: (1) bias arising from the randomization process, (2) bias due to deviations from the intended intervention, (3) bias due to missing outcome data, (4) bias in measurement of the outcome, and (5) bias in selection of the reported result. There were no concerns of bias with regards to allocation concealment and the randomization process of the 48 included studies. Furthermore, little reporting bias was noted among the included studies, as studies reported all statistics based on protocols and as per hypothesis. With regards to bias arising from deviations from the intended intervention, some studies resulted in moderate to high bias due to a lack of blinding participants, personnel and/or outcome assessors. For instance, in a study assigning participants to a physical intervention group with a regimented exercise schedule versus the control group, the physical intervention group could be more motivated to exercise and result in more exaggerated outcomes beyond the intended measurement. Furthermore, several studies had significant issues with 
attrition. Thus, bias was present in the domains of: bias due to deviations from the intended intervention, bias due to missing outcome data, and bias in measurement of the outcome. The ROBVIS software (Figure 2) was used to visualize these scores.

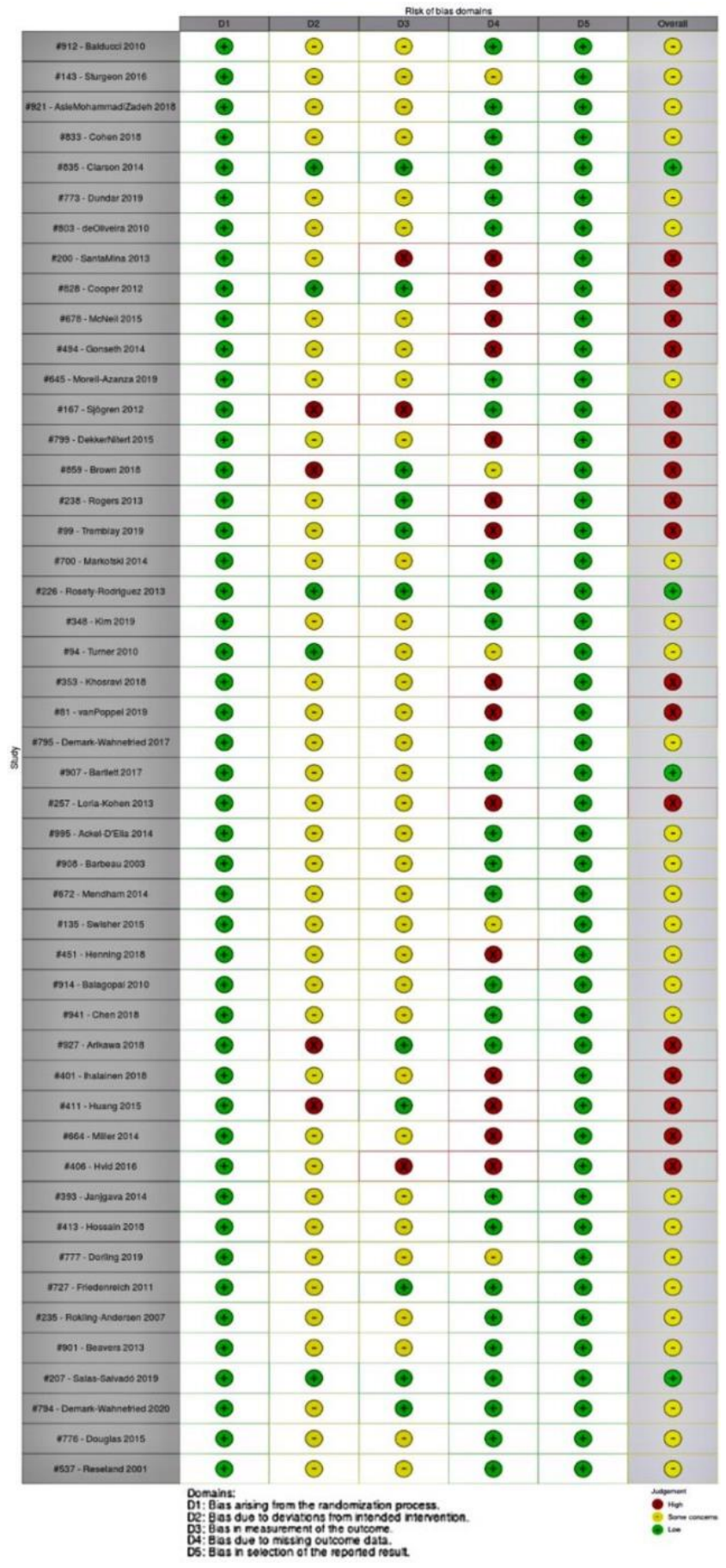

Figure 2. Risk of bias of the studies included in the systematic review using the Cochrane ROB2 tool.
Statistical Analysis

Using GraphPad Prism, results for the three two-tailed paired t-tests were obtained. In terms of the relationship between risk of bias and impact factor, the mean difference between the low/some risk group and high risk group was 0.2775 with a p-value $>0.6405$. Similarly, the relationships between risk of bias and author number or citation number yielded a mean difference of 2.059 with a p-value $>0.0962$ and a mean difference of -5.235 with a p-value $>0.5551$, respectively.

\section{Discussion}

Leptin is generally synthesized and secreted by white adipose tissue and acts on the hypothalamus to regulate energy homeostasis. Leptin is also found in the ovary, skeletal muscle, pituitary gland, and some lymphoid tissue. Leptin synthesis is stimulated by estrogen and is inhibited by testosterone. It is increased by glucocorticoids, proinflammatory cytokines and insulin [26]. Conversely, it is decreased by catecholamines. This systematic review found that circulating leptin levels are inversely proportional to the amount of physical activity [15]. Herein, we describe the mechanism of leptin, a hormone with a sexually dimorphic expression, and its effects on obesity.

Leptin mediates its effects by binding to leptin receptors (Figure 3). There are a multitude of alternatively spliced isoforms, but the most common one is the long isoform (LepRb) and is responsible for leptin signalling [38]. When leptin is secreted, it binds to LepRb and subsequently activates Janus kinase 2 (JAK2)/Signal transducer and activator of transcription 3 (STAT3). JAK2 phosphorylates itself and Tyrosine 985 (Tyr985), Tyr1077 and Tyr1138 of LepRb [30]. Activated STAT3 dimers will translocate to the cell nucleus and activate the transcription of target genes that mediate leptin's effect [30]. Protein tyrosine phosphatase 1B inhibits leptin signaling through dephosphorylation of JAK2 and regulates this in a negative feedback manner [29]. Downstream, AMP-activated protein kinase (AMPK) and phosphoinositide 3-kinase (P13K) are activated which eventually phosphorylates the mammalian target of rapamycin (mTOR) [18]. mTOR is a central regulator of cell metabolism, growth, survival and proliferation and thus has many implications in adiposity. Current studies suggest that overactivation of mTOR causes elevated serine phosphorylation of insulin receptor substrate 1 (IRS-1), which leads to impaired insulin signalling to protein kinase B (Akt), contributing to the development of obesity [18]. 


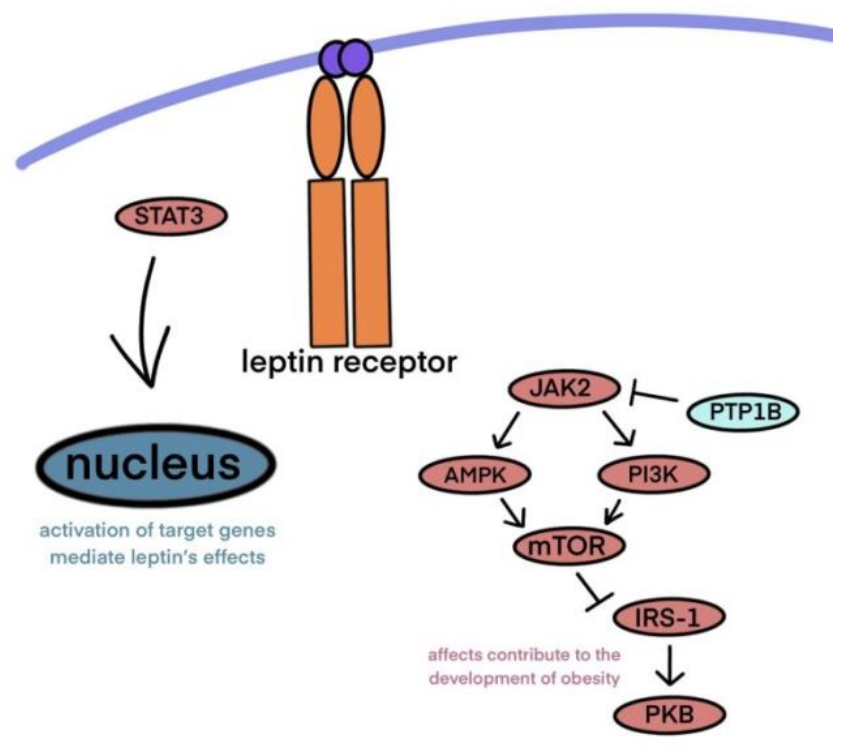

Figure 3. Overview of the leptin signalling pathway illustrating signalling factors involved in mediating leptin's effects.

Our systematic review finds that physical activity inhibits mTOR, which promotes insulin sensitization, promotes fat-loss, and reduces leptin expression and signalling. Of the forty-eight studies, thirty-nine studies reported that physical exercise results in a statistically significant decrease in leptin levels as compared to the control group. This supports the notion that weight loss, which is attributed to reduced fat, results in lower leptin levels. However, nine studies reported that physical exercise can result in no change or even an increase in leptin levels. This may be due to variability in the studies at the current level of statistical power. As a result, this highlights the varying relationship between leptin, physical activity and adiposity, and is an area of research that still needs to be further analyzed.

In terms of the risk of bias analysis, statistical analysis yielded no difference between high risk of bias studies and some/low risk of bias studies in relation to the number of authors, number of citations, journal impact factor and change in leptin ( $p>0.05)$. As a result, no conclusions can be made as to whether impact factor, citation number and journal impact factor can be used as a marker of whether a study should be used in clinical practice. However, further research is recommended to validate and explore the relationship between quality of research and variability in measurement of physical interventions. For instance, with a larger sample size of studies, an analysis which includes three categories, low risk, some concerns and high risk, as opposed to two categories can be conducted. The following analysis can yield more accurate information on the relationship between risk of bias and the characteristics examined above.

Tehfe et al. | URNCST Journal (2021): Volume 5, Issue 6 DOI Link: https://doi.org/10.26685/urnest.239

\section{Conclusion}

The narrative review has highlighted that there is an inverse correlation between physical exercise and leptin. Specifically, an overactivation of mTOR contributes to the development of obesity, with this pathway being inhibited by physical activity. By better understanding the relationship between the leptin pathway, physical activity and mTOR, clinicians can implement this learning into practice and aid in curbing society's increasingly prevalent issue of obesity. Further research is needed to address the varying effects of physical activity on leptin and to define a more concrete relationship between risk of bias and the characteristics of studies in this field.

\section{List of Abbreviations}

RCT: randomized control trial

ROB: risk of bias

BMI: body mass index

PRISMA: preferred reporting items for systematic reviews and meta-analyses

mTOR: mammalian target of rapamycin

IRS-1: insulin receptor substrate 1

Akt: protein kinase B

P13K: phosphoinositide 3-kinase

LepRb: leptin isoform

JAK2: janus kinase 2

STAT3: signal transducer and activator of transcription 3

Tyr: tyrosine

AMPK: AMP-activated protein kinase

\section{Conflicts of Interest}

The authors report no competing conflicts of interest.

\section{Ethics Approval and/or Participant Consent}

The study type, a systematic review, does not require ethics approval or participant consent.

\section{Authors' Contributions}

RT: made substantial contributions to the design of the study, the collection of data as well as interpretation and analysis of the data, and wrote and revised the manuscript critically.

ZE: made substantial contributions to the design of the study, the collection of data as well as interpretation and analysis of the data, and wrote and revised the manuscript critically.

HT: contributed to resolving conflict in the process of study selection, data extraction and ROB analysis, and revised the manuscript critically.

SF: contributed to resolving conflict in the process of study selection, data extraction and ROB analysis, and revised the manuscript critically.

\section{Funding}

This study was not funded. 
UNDERGRADUATE RESEARCH IN NATURAL AND CLINICAL SCIENCE AND TECHNOLOGY (URNCST) JOURNAL Read more URNCST Journal articles and submit your own today at: https://www.urncst.com

\section{References}

[1] Ahima RS, Flier JS. Leptin. Annu Rev Physiol. 2000 Mar;62(1):413-37. https://doi.org/10.1146/annurev .physiol.62.1.413

[2] Sahu A. Minireview: A hypothalamic role in energy balance with special emphasis on leptin. Endocrinology. 2004 Jun 1;145(6):2613-20. https://doi.org/10.1210/ en.2004-0032

[3] Zhang Y, Scarpace PJ. The role of leptin in leptin resistance and obesity. Physiology \& behavior. 2006 Jun 30;88(3):249-56. https://doi.org/10.1016/j.physbeh $\underline{.2006 .05 .038}$

[4] Wadden TA, Considine RV, Foster GD, Anderson DA, Sarwer DB, Caro JS. Short-and long-term changes in serum leptin in dieting obese women: Effects of caloric restriction and weight loss. The Journal of Clinical Endocrinology \& Metabolism. 1998 Jan 1;83(1):214-8. https://doi.org/10.1210/jcem.83.1.4494

[5] Wolfe BE, Jimerson DC, Orlova C, Mantzoros CS. Effect of dieting on plasma leptin, soluble leptin receptor, adiponectin and resistin levels in healthy volunteers. Clinical endocrinology. 2004 Sep;61(3):3328. https://doi.org/10.1111/j.1365-2265.2004.02101.x

[6] Farooqi IS, Jebb SA, Langmack G, Lawrence E, Cheetham CH, Prentice AM, Hughes IA, McCamish MA, O'Rahilly S. Effects of recombinant leptin therapy in a child with congenital leptin deficiency. New England journal of medicine. 1999 Sep 16;341(12):87984. https://doi.org/10.1056/nejm199909163411204

[7] Kraemer RR, Chu H, Castracane VD. Leptin and exercise. Experimental Biology and Medicine. 2002 Oct;227(9):701-8. https://doi.org/10.1177/15353702022 2700903

[8] Pérusse L, Collier G, Gagnon J, Leon AS, Rao DC, Skinner JS, Wilmore JH, Nadeau A, Zimmet PZ, Bouchard C. Acute and chronic effects of exercise on leptin levels in humans. Journal of applied physiology. 1997 Jul 1;83(1):5-10. https://doi.org/10.1152/jappl .1997 .83 .1 .5

[9] Landt M, Lawson GM, Helgeson JM, Davila-Roman VG, Ladenson JH, Jaffe AS, Hickner RC. Prolonged exercise decreases serum leptin concentrations. Metabolism. 1997 Oct 1;46(10):1109-12. https://doi.org/10.1016/s0026-0495(97)90200-6

[10] Bouassida A, Zalleg D, Bouassida S, Zaouali M, Feki Y, Zbidi A, et al. Leptin, its implication in physical exercise and training: a short review. J Sports Sci Med. 2006;5(2):172-81.

[11] van Poppel MNM, Simmons D, Devlieger R, van Assche FA, Jans G, Galjaard S, et al. A reduction in sedentary behaviour in obese women during pregnancy reduces neonatal adiposity: The DALI randomised controlled trial. Diabetologia. 2019 Jun;62(6):915-25. https://doi.org/10.1007/s00125-019-4842-0

Tehfe et al. | URNCST Journal (2021): Volume 5, Issue 6 DOI Link: https://doi.org/10.26685/urnest.239
[12] Chen Y-C, Betts JA, Walhin J-P, Thompson D. Adipose tissue responses to breaking sitting in men and women with central adiposity. Medicine \& Science in Sports \& Exercise. 2018 Oct;50(10):2049-57. https://doi.org/10.1249/mss.0000000000001654

[13] Balducci S, Zanuso S, Nicolucci A, Fernando F, Cavallo S, Cardelli P, et al. Anti-inflammatory effect of exercise training in subjects with type 2 diabetes and the metabolic syndrome is dependent on exercise modalities and independent of weight loss. Nutrition, Metabolism and Cardiovascular Diseases. 2010 Oct;20(8):608-17. https://doi.org/10.1016/j.numecd.2009.04.015

[14] Douglas JA, King JA, McFarlane E, Baker L, Bradley C, Crouch N, et al. Appetite, appetite hormone and energy intake responses to two consecutive days of aerobic exercise in healthy young men. Appetite. 2015 Sep;92:57-65. https://doi.org/10.1016/j.appet.2015.05 .006

[15] Dundar A, Kocahan S, Sahin L. Associations of apelin, leptin, irisin, ghrelin, insulin, glucose levels, and lipid parameters with physical activity during eight weeks of regular exercise training. Archives of Physiology and Biochemistry. 2019 Jul 10;1-5. https://doi.org/ $\underline{10.1080 / 13813455.2019 .1635622}$

[16] Balagopal PB, Gidding SS, Buckloh LM, Yarandi HN, Sylvester JE, George DE, et al. Changes in circulating satiety hormones in obese children: A randomized controlled physical activity-based intervention study. Obesity. 2010 Sep;18(9):1747-53. https://doi.org/ 10.1038/oby.2009.498

[17] Cohen TR, Hazell TJ, Vanstone CA, Rodd C, Weiler HA. Changes in eating behavior and plasma leptin in children with obesity participating in a family-centered lifestyle intervention. Appetite. 2018 Jun;125:81-9. https://doi.org/10.1016/j.appet.2018.01.017

[18] Friedenreich CM, Neilson HK, Woolcott CG, McTiernan A, Wang Q, Ballard-Barbash R, et al. Changes in insulin resistance indicators, IGFs, and adipokines in a year-long trial of aerobic exercise in postmenopausal women. Endocrine Related Cancer. 2011 Jun 8;18(3):357-69. https://dx.doi.org/10.1530\% 2FERC-10-0303

[19] McNeil J, Schwartz A, Rabasa-Lhoret R, Lavoie J-M, Brochu M, Doucet É. Changes in leptin and peptide YY do not explain the greater-than-predicted decreases in resting energy expenditure after weight loss. The Journal of Clinical Endocrinology \& Metabolism. 2015 Mar;100(3):E443-52. https://doi.org/10.1210/jc.20142210

[20] Morell-Azanza L, Ojeda-Rodríguez A, OchotorenaElicegui A, Martín-Calvo N, Chueca M, Marti A, et al. Changes in objectively measured physical activity after a multidisciplinary lifestyle intervention in children with abdominal obesity: A randomized control trial. BMC Pediatr. 2019 Dec;19(1):90. https://doi.org/ $\underline{10.1186 / \mathrm{s} 12887-019-1468-9}$ 
UNDERGRADUATE RESEARCH IN NATURAL AND CLINICAL SCIENCE AND TECHNOLOGY (URNCST) JOURNAL Read more URNCST Journal articles and submit your own today at: https://www.urncst.com

[21] Ihalainen JK, Schumann M, Eklund D, Hämäläinen M, Moilanen E, Paulsen G, et al. Combined aerobic and resistance training decreases inflammation markers in healthy men. Scand J Med Sci Sports. 2018 Jan;28(1):40-7. https://doi.org/10.1111/sms.12906

[22] Asle Mohammadi Zadeh M, Kargarfard M, Marandi SM, Habibi A. Diets along with interval training regimes improves inflammatory \& anti-inflammatory condition in obesity with type 2 diabetes subjects. J Diabetes Metab Disord. 2018 Dec;17(2):253-67. https://doi.org/10.1007/s40200-018-0368-0

[23] Khosravi N, Eskandari Z, Farajivafa V, Hanson E, Agha-alinejad H, Abdollah-pour A, et al. Effect of 6 months of aerobic training on adipokines as breast cancer risk factors in postmenopausal women: A randomized controlled trial. J Can Res Ther. 2018;0(0):0. https://doi.org/10.4103/jcrt.jcrt_684_16

[24] Hvid T, Lindegaard B, Winding K, Iversen P, Brasso K, Solomon TPJ, et al. Effect of a 2-year home-based endurance training intervention on physiological function and PSA doubling time in prostate cancer patients. Cancer Causes Control. 2016 Feb;27(2):16574. https://dx.doi.org/10.1016\%2Fj.bjmsu.2011.08.006

[25] Salas-Salvadó J, Díaz-López A, Ruiz-Canela M, Basora J, Fitó M, Corella D, et al. Effect of a lifestyle intervention program with energy-restricted mediterranean diet and exercise on weight loss and cardiovascular risk factors: One-year results of the PREDIMED-plus trial. Dia Care. 2018 Nov 2;dc180836. https://doi.org/10.2337/dc18-0836

[26] Loria-Kohen V, Fernández-Fernández C, Bermejo LM, Morencos E, Romero-Moraleda B, Gómez-Candela C. Effect of different exercise modalities plus a hypocaloric diet on inflammation markers in overweight patients: A randomised trial. Clinical Nutrition. 2013

Aug;32(4):511-8. https://doi.org/10.1016/j.clnu.2012.10 .015

[27] Reseland JE, Anderssen SA, Solvoll K, Hjermann I, Urdal P, Holme I, et al. Effect of long-term changes in diet and exercise on plasma leptin concentrations. The American Journal of Clinical Nutrition. $2001 \mathrm{Feb}$ 1;73(2):240-5. https://doi.org/10.1093/ajcn/73.2.240

[28] de Oliveira DCX, Rossano Procida I, das Neves Borges-Silva C. Effect of training judo in the competition period on the plasmatic levels of leptin and pro-inflammatory cytokines in high-performance male athletes. Biol Trace Elem Res. 2010 Jun;135(1-3):34554. https://doi.org/10.1007/s12011-009-8499-2

[29] Miller GD, Isom S, Morgan TM, Vitolins MZ, Blackwell C, Brosnihan KB, et al. Effects of a community-based weight loss intervention on adipose tissue circulating factors. Diabetes \& Metabolic Syndrome: Clinical Research \& Reviews. 2014 Oct;8(4):205-11. https://dx.doi.org/10.1016\%2Fj.dsx .2014 .09 .003

Tehfe et al. | URNCST Journal (2021): Volume 5, Issue 6 DOI Link: https://doi.org/10.26685/urncst.239
[30] Clarson CL, Brown HK, De Jesus S, Jackman M, Mahmud FH, Prapavessis H, et al. Effects of a comprehensive, intensive lifestyle intervention combined with metformin extended release in obese adolescents. International Scholarly Research Notices. 2014 Nov 10;2014:1-13. https://doi.org/10.1155/2014/ $\underline{659410}$

[31] Huang T, Larsen KT, Møller NC, Ried-Larsen M, Frandsen U, Andersen LB. Effects of a multi-component camp-based intervention on inflammatory markers and adipokines in children: A randomized controlled trial. Preventive Medicine. 2015 Dec;81:367-72. https://dx.doi.org/10.1002\%2F14651858.CD009728 .pub4

[32] Arikawa AY, Kaufman BC, Raatz SK, Kurzer MS. Effects of a parallel-arm randomized controlled weight loss pilot study on biological and psychosocial parameters of overweight and obese breast cancer survivors. Pilot Feasibility Stud. 2018 Dec;4(1):17. https://doi.org/10.1186/s40814-017-0160-9

[33] Rogers LQ, Fogleman A, Trammell R, Hopkins-Price P, Vicari S, Rao K, et al. Effects of a physical activity behavior change intervention on inflammation and related health outcomes in breast cancer survivors: Pilot randomized trial. Integr Cancer Ther. 2013 Jul;12(4):323-35. https://doi.org/10.1177/1534735412 449687

[34] Cooper JN, Columbus ML, Shields KJ, Asubonteng J, Meyer ML, Sutton-Tyrrell K, et al. Effects of an intensive behavioral weight loss intervention consisting of caloric restriction with or without physical activity on common carotid artery remodeling in severely obese adults. Metabolism. 2012 Nov;61(11):1589-97. https://doi.org/10.1016/j.metabol.2012.04.012

[35] Ackel-D'Elia C, Carnier J, Bueno C, Campos RM, Sanches P, Clemente AP, et al. Effects of different physical exercises on leptin concentration in obese adolescents. Int J Sports Med. 2013 Jul 18;35(02):16471. https://doi.org/10.1055/s-0033-1345128

[36] Rokling-Andersen MH, Reseland JE, Veierød MB, Anderssen SA, Jacobs DR, Urdal P, et al. Effects of long-term exercise and diet intervention on plasma adipokine concentrations. The American Journal of Clinical Nutrition. 2007 Nov 1;86(5):1293-301. https://dx.doi.org/10.3390\%2Fmedsci6040097

[37] Swisher AK, Abraham J, Bonner D, Gilleland D, Hobbs G, Kurian S, et al. Exercise and dietary advice intervention for survivors of triple-negative breast cancer: Effects on body fat, physical function, quality of life, and adipokine profile. Support Care Cancer. 2015 Oct;23(10):2995-3003. https://doi.org/10.1007/ $\underline{\mathrm{s} 00520-015-2667-\mathrm{Z}}$ 
UNDERGRADUATE RESEARCH IN NATURAL AND CLINICAL SCIENCE AND TECHNOLOGY (URNCST) JOURNAL Read more URNCST Journal articles and submit your own today at: https://www.urncst.com

[38] Santa Mina D, Connor MK, Alibhai SMH, Toren P, Guglietti C, Matthew AG, et al. Exercise effects on adipokines and the IGF axis in men with prostate cancer treated with androgen deprivation: A randomized study. CUAJ. 2013 Nov 8;7(11-12):692. https://dx.doi.org/10.5489\%2Fcuaj.235

[39] Dekker Nitert M, Barrett HL, Denny KJ, McIntyre HD, Callaway LK, the BAMBINO group. Exercise in pregnancy does not alter gestational weight gain, $\mathrm{MCP}$ 1 or leptin in obese women. Aust N Z J Obstet Gynaecol. 2015 Feb;55(1):27-33. https://doi.org/ $\underline{10.1111 / \text { ajo.12300 }}$

[40] Markofski MM, Carrillo AE, Timmerman KL, Jennings $\mathrm{K}$, Coen PM, Pence BD, et al. Exercise training modifies ghrelin and adiponectin concentrations and is related to inflammation in older adults. The Journals of Gerontology Series A: Biological Sciences and Medical Sciences. 2014 Jun 1;69(6):675-81. https://dx.doi.org/10.1093\%2Fgerona\%2Fglt132

[41] Sturgeon K, Digiovanni L, Good J, Salvatore D, Fenderson D, Domchek S, et al. Exercise-induced doseresponse alterations in adiponectin and leptin levels are dependent on body fat changes in women at risk for breast cancer. Cancer Epidemiol Biomarkers Prev. 2016 Aug;25(8):1195-200. https://doi.org/10.1158/1055-9965 .epi-15-1087

[42] Sjögren P, Sierra-Johnson J, Kallings LV, Cederholm T, Kolak M, Halldin M, et al. Functional changes in adipose tissue in a randomised controlled trial of physical activity. Lipids Health Dis. 2012;11(1):80. https://doi.org/10.1186/1476-511x-11-80

[43] Beavers KM, Ambrosius WT, Nicklas BJ, Rejeski WJ. Independent and Combined Effects of physical activity and weight loss on inflammatory biomarkers in overweight and obese older adults. J Am Geriatr Soc. 2013 Jul;61(7):1089-94. https://doi.org/10.1111/jgs .12321

[44] Barbeau P, Gutin B, Litaker MS, Ramsey LT, Cannady WE, Allison J, et al. Influence of physical training on plasma leptin in obese youths. Can J Appl Physiol. 2003 Jun 1;28(3):382-96. https://doi.org/10.1139/h03-028

[45] Janjgava S, Zerekidze T, Uchava L, Giorgadze E, Asatiani K. Influence of testosterone replacement therapy on metabolic disorders in male patients with type 2 diabetes mellitus and androgen deficiency. Eur J Med Res. 2014 Dec;19(1):56. https://doi.org/ 10.1186/s40001-014-0056-6

[46] Gonseth S, Locatelli I, Bize R, Nusslé S, Clair C, Pralong F, et al. Leptin and smoking cessation: secondary analyses of a randomized controlled trial assessing physical activity as an aid for smoking cessation. BMC Public Health. 2014 Dec;14(1):911. https://doi.org/10.1186/1471-2458-14-911
[47] Tremblay A, Dutheil F, Drapeau V, Metz L, Lesour B, Chapier R, et al. Long-term effects of high-intensity resistance and endurance exercise on plasma leptin and ghrelin in overweight individuals: the RESOLVE Study. Appl Physiol Nutr Metab. 2019 Nov;44(11):1172-9. https://doi.org/10.1139/apnm-2019-0019

[48] Bartlett DB, Shepherd SO, Wilson OJ, Adlan AM, Wagenmakers AJM, Shaw CS, et al. Neutrophil and monocyte bactericidal responses to 10 weeks of lowvolume high-intensity interval or moderate-intensity continuous training in sedentary adults. Oxidative Medicine and Cellular Longevity. 2017;2017:1-12. https://doi.org/10.1155/2017/8148742

[49] Turner JE, Markovitch D, Betts JA, Thompson D. Nonprescribed physical activity energy expenditure is maintained with structured exercise and implicates a compensatory increase in energy intake. The American Journal of Clinical Nutrition. 2010 Nov 1;92(5):100916. https://doi.org/10.3945/ajcn.2010.29471

[50] Henning SM, Galet C, Gollapudi K, Byrd JB, Liang P, $\mathrm{Li} \mathrm{Z}$, et al. Phase II prospective randomized trial of weight loss prior to radical prostatectomy. Prostate Cancer Prostatic Dis. 2018 Jun;21(2):212-20. https://dx.doi.org/10.1038\%2Fs41391-017-0001-1

[51] Demark-Wahnefried W, Rais-Bahrami S, Desmond RA, Gordetsky JB, Hunter GR, Yang ES, et al. Presurgical weight loss affects tumour traits and circulating biomarkers in men with prostate cancer. $\mathrm{Br}$ J Cancer. 2017 Oct;117(9):1303-13. https://dx.doi.org/ $10.1038 \% 2$ Fbjc. 2017.303

[52] Dorling JL, Church TS, Myers CA, Höchsmann C, White UA, Hsia DS, et al. Racial variations in appetiterelated hormones, appetite, and laboratory-based energy intake from the E-MECHANIC randomized clinical trial. Nutrients. 2019 Aug 28;11(9):2018. https://dx.doi.org/10.3390\%2Fnu11092018

[53] Brown JC, Yung RL, Gobbie-Hurder A, Shockro L, O'Connor K, Campbell N, et al. Randomized trial of a clinic-based weight loss intervention in cancer survivors. J Cancer Surviv. 2018 Apr;12(2):186-95. https://doi.org/10.1007/s11764-017-0657-5

[54] Demark-Wahnefried W, Rogers LQ, Gibson JT, Harada S, Frugé AD, Oster RA, et al. Randomized trial of weight loss in primary breast cancer: Impact on body composition, circulating biomarkers and tumor characteristics. Int J Cancer. 2020 May 15;146(10):2784-96. https://doi.org/10.1002/ijc.32637

[55] Ordonez FJ. Resistance circuit training reduced inflammatory cytokines in a cohort of male adults with Down syndrome. Med Sci Monit. 2013;19:949-53. https://dx.doi.org/10.12659\%2FMSM.889362

[56] Mendham AE, Duffield R, Marino F, Coutts AJ. Small-sided games training reduces CRP, IL-6 and leptin in sedentary, middle-aged men. Eur J Appl Physiol. 2014 Nov;114(11):2289-97. https://doi.org/ 10.1007/s00421-014-2953-3 
UNDERGRADUATE RESEARCH IN NATURAL AND CLINICAL SCIENCE AND TECHNOLOGY (URNCST) JOURNAL Read more URNCST Journal articles and submit your own today at: https://www.urncst.com

[57] Kim S-W, Jung W-S, Park W, Park H-Y. Twelve weeks of combined resistance and aerobic exercise improves cardiometabolic biomarkers and enhances red blood cell hemorheological function in obese older men: A randomized controlled trial. IJERPH. 2019 Dec 10;16(24):5020. https://dx.doi.org/10.3390\%2Fijerph $\underline{16245020}$
[58] Hossain MJ, Levinson A, George D, Canas J, Kumar S, Balagopal PB. Vitamin D status and cardiovascular risk in obesity: Effect of physical activity in nonvitamin D supplemented adolescents. Metabolic Syndrome and Related Disorders. 2018 May;16(4):197-203. https://doi.org/10.1089/met.2017.0171

\section{Article Information}

Managing Editor: Jeremy Y. Ng

Peer Reviewers: Emma Nicholson, Pallavi Dutta

Article Dates: Received Jan 01 21; Accepted Mar 30 21; Published Jun 0821

\section{Citation}

Please cite this article as follows:

Tehfe RH, Elkhansa ZA, Fu S, Tehfe H. The effect of exercise on leptin and adiposity: A systematic review. URNCST Journal. 2021 Jun 08: 5(6). https://urncst.com/index.php/urncst/article/view/239

DOI Link: https://doi.org/10.26685/urncst.239

\section{Copyright}

(C) Reem H. Tehfe, Zaynab A. Elkhansa, Sarah Fu, Hadi Tehfe. (2021). Published first in the Undergraduate Research in Natural and Clinical Science and Technology (URNCST) Journal. This is an open access article distributed under the terms of the Creative Commons Attribution License (https://creativecommons.org/licenses/by/4.0/), which permits unrestricted use, distribution, and reproduction in any medium, provided the original work, first published in the Undergraduate Research in Natural and Clinical Science and Technology (URNCST) Journal, is properly cited. The complete bibliographic information, a link to the original publication on http://www.urncst.com, as well as this copyright and license information must be included.

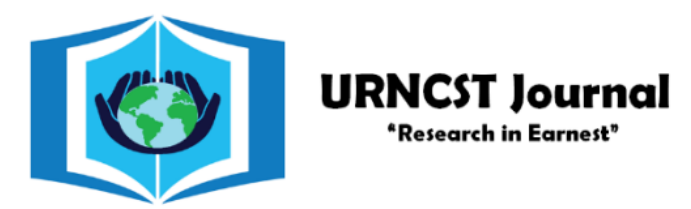

\section{Funded by the Government of Canada}

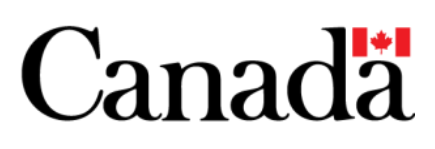

Do you research in earnest? Submit your next undergraduate research article to the URNCST Journal!

| Open Access | Peer-Reviewed | Rapid Turnaround Time | International |

| Broad and Multidisciplinary | Indexed | Innovative | Social Media Promoted |

Pre-submission inquiries? Send us an email at info@urncst.com | Facebook, Twitter and LinkedIn: @URNCST

Submit YOUR manuscript today at https://www.urncst.com! 